\title{
Quantitative Structure Inter-Activity Relationship (QSInAR). Cytotoxicity Study of Some Hemisynthetic and Isolated Natural Steroids and Precursors on Human Fibrosarcoma Cells HT1080
}

\author{
Mihai V. Putz ${ }^{1, *}$, Marius Lazea ${ }^{1}$ and Louis P. Sandjo ${ }^{1,2}$
}

1 Laboratory of Computational and Structural Physical Chemistry, Chemistry Department, West University of Timişoara, Pestalozzi Street No.16, Timişoara, RO-300115, Romania

2 Department of Organic Chemistry, University of Yaoundé 1 P.O. Box 812 Yaoundé, Cameroon

* Author to whom correspondence should be addressed; E-Mails: mvputz@cbg.uvt.ro or mv_putz@yahoo.com; Tel.: +40-256-592-633; Fax: +40-256-592-620.

Received: 30 June 2011; in revised form: 28 July 2011 / Accepted: 29 July 2011 /

Published: 5 August 2011

\begin{abstract}
Combined experimental and quantitative structure inter-activity relationship (QSIAR) computation methods were advanced in order to establish the structural and mechanistic influences that steroids and triterpenes, either as newly synthesized or naturally isolated products, have on human HT1080 mammalian cancer cells. The main Hansch structural indicators such as hydrophobicity (LogP), polarizability (POL) and total energy (Etot) were considered and both the structure-projected as well as globally computed correlations were reported; while the inter-activity correlation of the global activity with those projected on structural information was revealed as equal to the direct structural-activity one for the trial sets of compounds, the prediction for the testing set of molecules reported even superior performances respecting those characteristic for the calibration set, validating therefore the present QSInAR models; accordingly, it follows that the LogP carries the most part of the cytotoxic signal, while POL has little influence on inhibiting tumor growth-A complementary behavior with their earlier known influence on genotoxic carcinogenesis. Regarding the newly hemisynthetic compounds it was found that stigmasta-4,22-dien-3-one is not adapted for cell membrane diffusion; it is recommended that aminocinnamyl chlorohydrate be further modified in order to acquire better steric influence, while aminocinnamyl-2,3,4,6-O-tétraacétyl- $\alpha$-D-glucopyranoside was identified as being inhibited in the tumor cell by other molecular mechanisms-here not revealed-although it has a moderate-high anti-cancer structurally predicted activity.
\end{abstract}


Keywords: steroids and triterpenes; organic synthesis; HT1080 cancer cell lines; cytotoxicity activity; Hansch indices; mono and multi-linear correlations

\section{Introduction}

Steroids and their triterpene precursors are both natural product classes widespread in plants and possessing a broad spectrum of biological activities. This family of secondary metabolites is still a research target since many of its compounds such as betulinic, oleanolic and ursolic acids have been reported as antitumor agents [1], while stigmasterol which is one of the biosynthetic descents of triterpenes have significant anticancer activity [2], analgesic [3] and hypoglycemic effects [4]. Moreover, many previous studies have shown that some phytocomponents related to cholesterol presented antimalarial activities [5], or induced apoptosis [6]. However, most of steroids presented in the literature as cytotoxic compounds are polyhydroxylated or contain a $\alpha, \beta$-unsaturated ketone function [7-10]. Besides, these terpenoids caused cell death when they are presented as sulfate [11] or quaternary ammonium salts [12].

On the other side, apart of (hemi)synthesis and isolation of natural products the identification of their anti-cancer molecular mechanism represents one of the main current research concerns [13,14]. In this regard, chemoinformatics in general [15] and the recent spectral and residual variants of quantitative structure-activity relationship (QSAR) in particular [16,17], may offer a reliable in silico (or computational) analysis for establishing whether a series of compounds may indeed constitute a fruitful direction of clinical investigations. Basically, the cytotoxic molecular mechanism may be decomposed into three elementary steps: The compound effect on membrane structure, on the signal transduction pathways, and on sterical induction signal towards the cancer cells; these effects can be structurally modeled by the so called Hansch indices' [18] such as hydrophobicity $(\log P)$, polarizability (POL) and optimized total energy (Etot) influence on the globally observed cytotoxic activity (A), respectively. However, having to account on the cumulative effect of each of these steps in producing the recorded output of programmed cancer cell death, a sort of inter-activity QSAR should be investigated, i.e., by correlating the overall cytotoxic activity with its projection on structurally-based independent activities for the above Hansch indicators. Such a study is to be in the present report unfolded upon a congeneric class of steroids and triterpenes, among which some new hemisynthetic ones were also included.

\section{Chemistry and Cytotoxicity Assay}

With the aim to discovering new bioactive components, chemical transformations of stigmasterol were carried out following the route reaction described by Syamala et al. [19] (Scheme 1) while the oxidation reaction with pyridinium chlorochromate (PCC) presented was performed as reported by Li et al. [20]. For instance, the preparation of aminocinnamyl chlorohydrate was done following the reaction of Scheme 2 [21], while the $\alpha$-glucosylation reaction is new and presented in Scheme 3.

From the compounds of Table 1, the semisynthetic three pentacyclic triterpenes [lupeol (1), oleanolic acid (2) and maslinic acid (10)] and two steroids (stigmasterol and sitosterol 3-O- $\beta$-D-gluco- 
pyranoside) isolated from the stems of cultivated Triumfetta cordifolia (Tiliaceae) were tested against HT1080 cancer cell lines, together with as well as the hemisynthetic steroids 3/G3, 4/G4 and 18 and two cinnamyl derivatives 5/G5, 11/G11.

Scheme 1. $\Delta^{5}$ epoxidation of steroids.
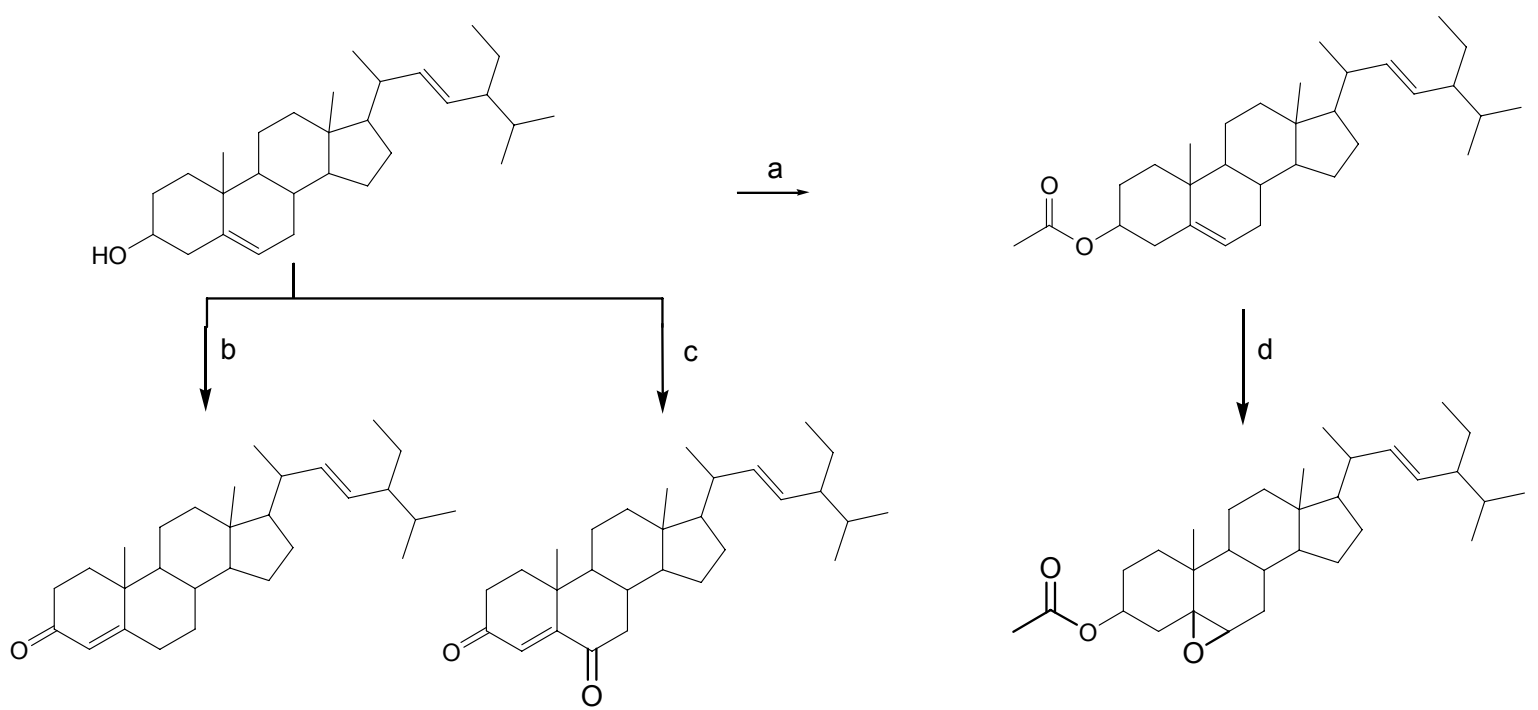

Reaction Conditions: (a) $\left(\mathrm{H}_{3} \mathrm{CCO}\right)_{2} \mathrm{O} / \mathrm{C}_{5} \mathrm{H}_{5} \mathrm{~N}(1 / 1) \mathrm{v} / \mathrm{v}$, r.t., $1 \mathrm{~h}$; (b) $\mathrm{CH}_{2} \mathrm{Cl}_{2}, \mathrm{PCC} / \mathrm{Al}_{2} \mathrm{O}_{3}$ (10 equiv.), under $\mathrm{N}_{2}, 24 \mathrm{~h}$; (c) $\mathrm{CH}_{2} \mathrm{Cl}_{2}, \mathrm{PCC} / \mathrm{Al}_{2} \mathrm{O}_{3}$ (10 equiv.), under $\mathrm{N}_{2}, 36$ h; (d) A mixture of $\mathrm{KMnO}_{4}(1.6 \mathrm{~g})$ and $\mathrm{CuSO}_{4} \cdot 5 \mathrm{H}_{2} \mathrm{O}(0.8 \mathrm{~g})$, Water $(0.3 \mathrm{~mL}), \mathrm{CH}_{2} \mathrm{Cl}_{2}(20 \mathrm{~mL})$, and stigmasteryl acetate $(0.37 \mathrm{mmol})$ followed by tert-butyl alcohol $(1 \mathrm{~mL})$ for a while and then cooled down after stirring for $2 \mathrm{~h}$ at r.t.

Scheme 2. Preparation of aminocinnamyl chlorohydrate.

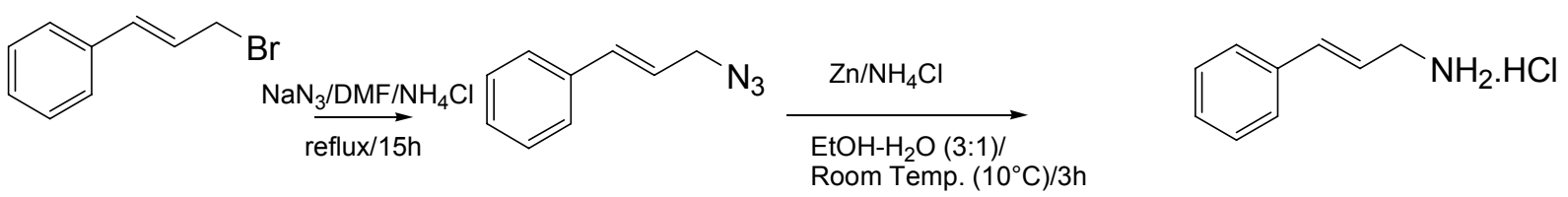

Scheme 3. $\alpha$-Glucosylation.
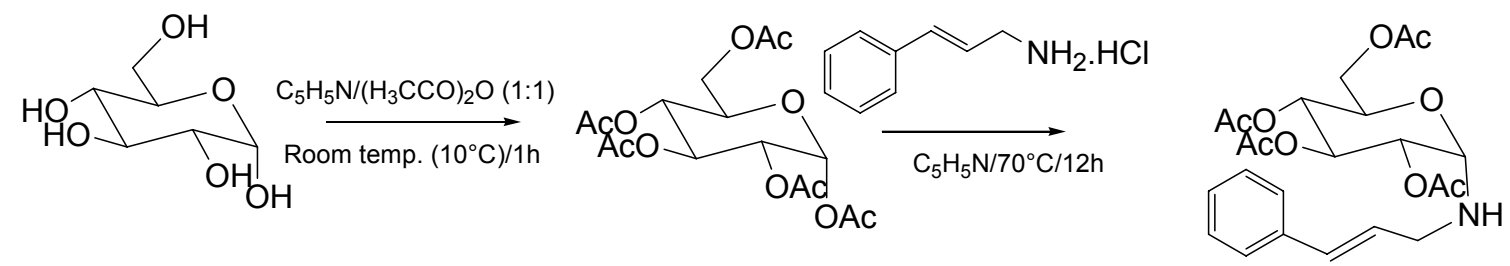

These cells are able to undergo physiological cell death, a process termed apoptosis [22], and are sensitive to a wide variety of cytotoxic drugs such as etoposide, cisplatin, staurosporine or TNF- $\alpha$. In order to avoid a putative toxicity of the solvents, the maximum used volume of the compound solution never exceeded $1 / 100$ of the total volume of culture medium. Controls with analogous concentrations of solvents were always carried out in parallel to check their lack of toxicity. Six compounds were prepared at $100 \mathrm{mM}$ allowing testing concentrations as high as $1 \mathrm{mM}$, whereas the other five compounds showed lower solubility, consequently eliminating the possibility to test such concentrations. 
Table 1. Some hemisynthetic and isolated natural products along their $\mathrm{IC}_{50}$ cytotoxic activity on human fribosarcoma cell HT1080 and the computed [23] QSAR properties for the Hansch parameters, i.e., hydrophobicity, polarizability and the (PM3) total energy.

\begin{tabular}{|c|c|c|c|c|c|c|c|}
\hline \multirow{2}{*}{$\begin{array}{l}\text { No. } \\
/ \mathrm{G} / \mathrm{NG} \text { * }\end{array}$} & \multirow{2}{*}{$\begin{array}{c}\text { Name } \\
\text { (Hemisynthetic, if any) }\end{array}$} & \multirow{2}{*}{$\begin{array}{l}\text { Chemical } \\
\text { Formula }\end{array}$} & \multirow[b]{2}{*}{ Structure } & \multirow{2}{*}{$\begin{array}{c}\mathrm{IC}_{50}(\mathrm{mM}) \\
\text { (observed hours) } \\
{\left[\mathrm{A}=\log _{10}\left(1 / \mathrm{IC}_{50}\right)\right]}\end{array}$} & \multicolumn{3}{|c|}{ QSAR properties } \\
\hline & & & & & $\log P$ & $\begin{array}{c}\text { Pol } \\
{\left[\AA^{3}\right]}\end{array}$ & $\begin{array}{c}- \text { Etot } \\
\text { (kcal/mol) }\end{array}$ \\
\hline $1 / \mathrm{G} 1$ & $\begin{array}{l}\text { lup-20(29)-en-3 } \beta \text {-ol } \\
\text { (Lupeol) }\end{array}$ & $\mathrm{C}_{30} \mathrm{H}_{50} \mathrm{O}$ & & $\begin{array}{c}1 \\
(48) \\
{[0.000]}\end{array}$ & 8.03 & 52.4 & 106582.9141 \\
\hline $2 / \mathrm{G} 2$ & $\begin{array}{c}\text { 3ß-hydroxyolean-12-en-28-oic acid } \\
\text { (Oleanolic acid) }\end{array}$ & $\mathrm{C}_{30} \mathrm{H}_{48} \mathrm{O}_{3}$ & & $\begin{array}{c}0.7 \\
(48) \\
{[0.155]}\end{array}$ & 7.32 & 53.12 & 119358.2422 \\
\hline $4 / \mathrm{G} 4$ & $\begin{array}{l}\text { Stigmasta-4,22-dien-3-one } \\
\text { (Hemisynthetic) }\end{array}$ & $\mathrm{C}_{29} \mathrm{H}_{46} \mathrm{O}$ & & $\begin{array}{c}0.3 \\
{[0.523]}\end{array}$ & 8.19 & 50.60 & 102422.1563 \\
\hline
\end{tabular}


Table 1. Cont.

\begin{tabular}{|c|c|c|c|c|c|c|c|}
\hline \multirow{2}{*}{$\begin{array}{c}\text { No. } \\
/ \mathrm{G} / \mathrm{NG} \text { * }\end{array}$} & \multirow{2}{*}{$\begin{array}{c}\text { Name } \\
\text { (Hemisynthetic, if any) }\end{array}$} & \multirow{2}{*}{$\begin{array}{l}\text { Chemical } \\
\text { Formula }\end{array}$} & \multirow[t]{2}{*}{ Structure } & \multirow{2}{*}{$\begin{array}{c}\mathrm{IC}_{50}(\mathrm{mM}) \\
\text { (observed hours) } \\
{\left[\mathrm{A}=\log _{10}\left(1 / \mathrm{IC}_{50}\right)\right]}\end{array}$} & \multicolumn{3}{|c|}{ QSAR properties } \\
\hline & & & & & $\log P$ & $\begin{array}{l}\text { Pol } \\
{\left[\AA^{3}\right]}\end{array}$ & $\begin{array}{c}\text {-Etot } \\
\text { (kcal/mol) }\end{array}$ \\
\hline $5 / \mathrm{G} 5$ & $\begin{array}{c}\text { Chlorhydrate } \\
\text { of Aminocinnamyl } \\
\text { (Hemisynthetic) }\end{array}$ & $\mathrm{C}_{9} \mathrm{H}_{12} \mathrm{ClN}$ & & $\begin{array}{c}0.1 \\
(48) \\
{[1.000]}\end{array}$ & 2.82 & 19.03 & 39170.58984 \\
\hline 6/G6 & $\begin{array}{c}\text { Acovenosigenin A } \\
\text { or } \\
1 \beta, 3 \beta, 14 \beta \text {-trihydroxycard-20(22)- } \\
\text { enolide }\end{array}$ & $\mathrm{C}_{23} \mathrm{H}_{34} \mathrm{O}_{5}$ & & $\begin{array}{l}0.0012 \\
{[2.921]}\end{array}$ & 2.07 & 41.55 & 108835.2969 \\
\hline 7/G7 & $\begin{array}{c}\text { Periplogenin } \\
\text { or } \\
3 \beta, 5 \beta, 14 \beta \text {-trihydroxycard-20(22)- } \\
\text { enolide }\end{array}$ & $\mathrm{C}_{23} \mathrm{H}_{34} \mathrm{O}_{5}$ & & $\begin{array}{l}0.00081 \\
{[4.092]}\end{array}$ & 1.89 & 41.55 & 108837.7656 \\
\hline 8/G8 & $\begin{array}{c}\text { Periplogenin } \\
\text { or } \\
\text { 3-O- } \beta \text {-D-glucopyranosyl-5 } \beta, 14 \beta- \\
\text { dihydroxycard-20(22)-enolide }\end{array}$ & $\mathrm{C}_{29} \mathrm{H}_{44} \mathrm{O}_{10}$ & & $\begin{array}{l}0.00016 \\
{[3.796]}\end{array}$ & 0.67 & 54.97 & 162652.2813 \\
\hline
\end{tabular}


Table 1. Cont.

\begin{tabular}{|c|c|c|c|c|c|c|c|}
\hline \multirow[b]{2}{*}{$\begin{array}{l}\text { No. } \\
/ \text { G/NG * }\end{array}$} & \multirow[b]{2}{*}{$\begin{array}{c}\text { Name } \\
\text { (Hemisynthetic, if any) }\end{array}$} & \multirow[b]{2}{*}{$\begin{array}{l}\text { Chemical } \\
\text { Formula }\end{array}$} & \multirow[b]{2}{*}{ Structure } & \multirow{2}{*}{$\begin{array}{c}\mathrm{IC}_{50}(\mathrm{mM}) \\
\text { (observed hours) } \\
{\left[\mathrm{A}=\log _{\mathbf{1 0}}\left(\mathbf{1} / \mathrm{IC}_{\mathbf{5 0}}\right)\right]}\end{array}$} & \multicolumn{3}{|c|}{ QSAR properties } \\
\hline & & & & & $\log P$ & $\begin{array}{l}\text { Pol } \\
{\left[\AA^{3}\right]}\end{array}$ & $\begin{array}{c}\text {-Etot } \\
\text { (kcal/mol) }\end{array}$ \\
\hline 9/G9 & $\begin{array}{c}17 \alpha-H \text {-digitoxigenin } \\
\text { or } \\
3 \beta, 14 \beta \text {-dihydroxycard-20(22)- } \\
\text { enolide }\end{array}$ & $\mathrm{C}_{23} \mathrm{H}_{34} \mathrm{O}_{4}$ & & $\begin{array}{l}0.0015 \\
{[2.823]}\end{array}$ & 3.04 & 40.91 & 102065.0234 \\
\hline 10/G10 & $\begin{array}{c}\text { 1 } \alpha, 2 \beta \text {-dihydroxyolean-12-en-28-oic } \\
\text { acid } \\
\text { (Maslinic acid) }\end{array}$ & $\mathrm{C}_{30} \mathrm{H}_{48} \mathrm{O}_{4}$ & & $\begin{array}{c}0.075 \\
(48) \\
{[1.125]}\end{array}$ & 6.55 & 53.76 & 126133.4297 \\
\hline 12/NG1 & $\begin{array}{c}\text { Ginsenoside } \\
20(S) \text {-protopanaxadiol } \\
\text { or } \\
3 \beta, 12 \beta, 20 \text { S-trihydroxydammar-24- } \\
\text { ene }\end{array}$ & $\mathrm{C}_{30} \mathrm{H}_{52} \mathrm{O}_{3}$ & & $\begin{array}{l}0.07678 \\
{[1.115]}\end{array}$ & 6.29 & 54.45 & 120871.4531 \\
\hline
\end{tabular}


Table 1. Cont.

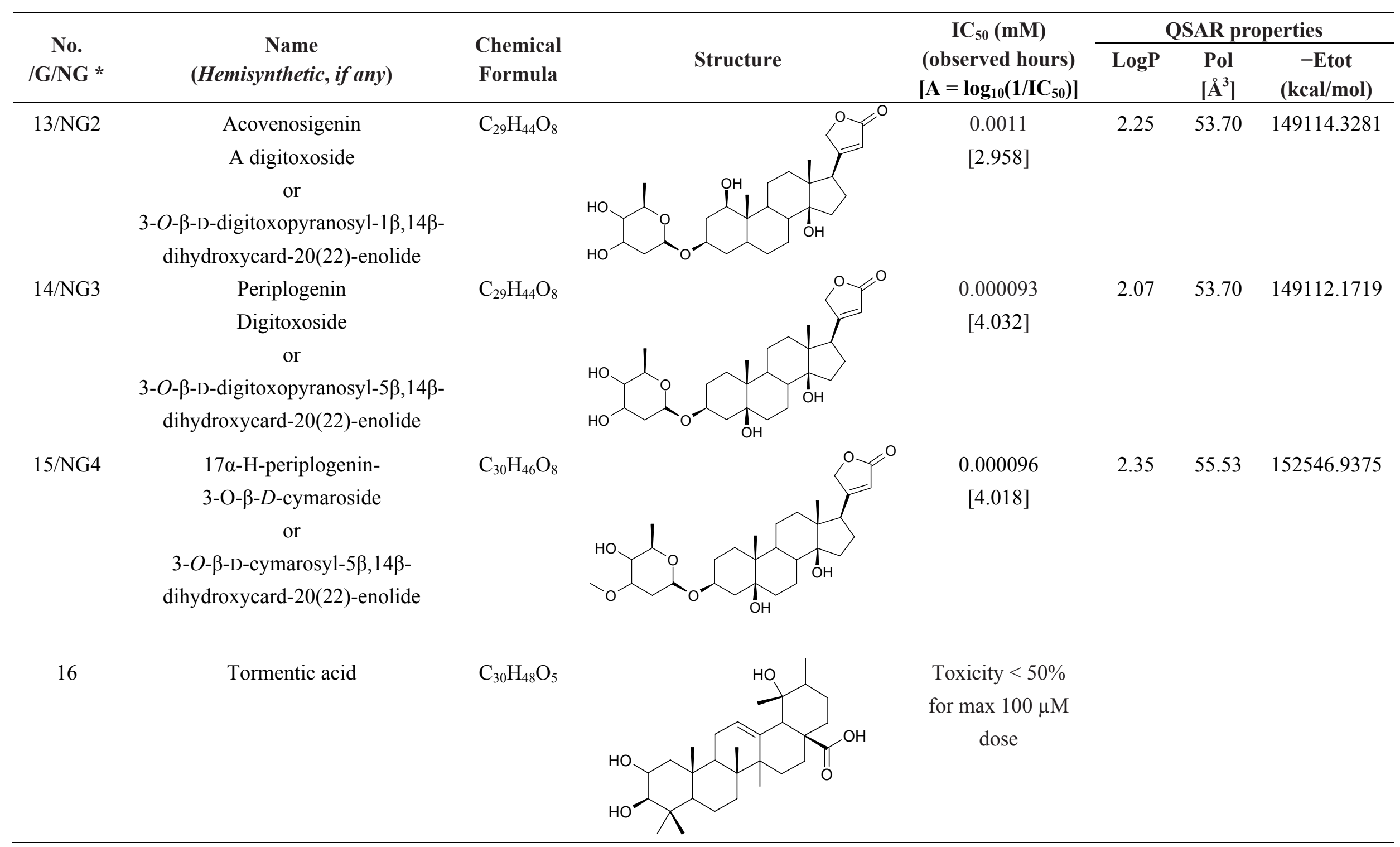


Table 1. Cont.

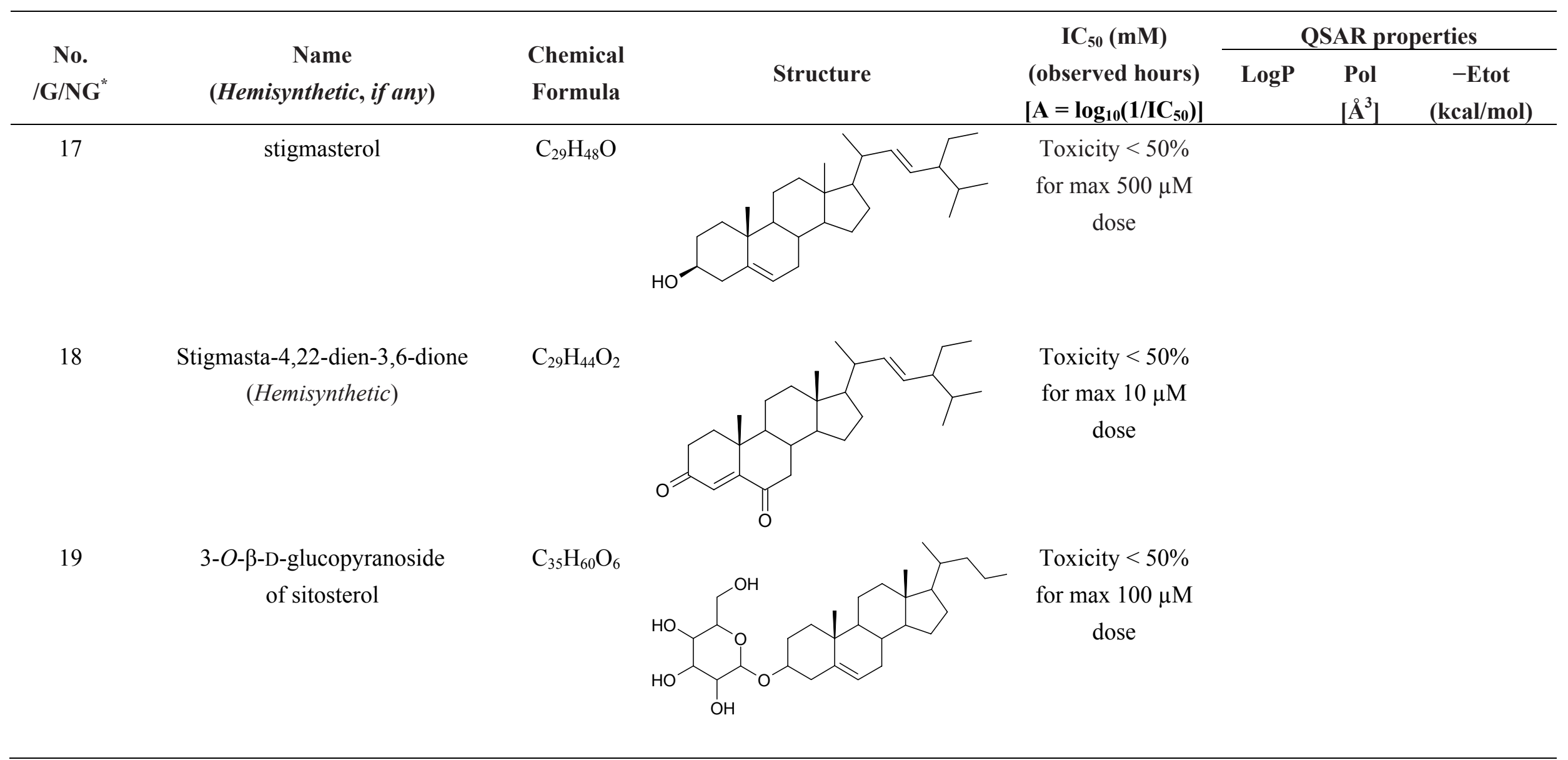

* Of Gaussian (G) or Non-Gaussian (NG) type, see Figure 1. 
Among these compounds (see Experimental section), four of them (molecules 16-19 of Table 1) induced less that $50 \%$ cell death after $48 \mathrm{~h}$ of treatment at maximum concentrations, rending impossible the determination of an $\mathrm{IC}_{50}$ : This was the case for tormentic acid $\left(\mathrm{C}_{\max }=100 \mu \mathrm{M}\right)$, stigmasterol $\left(\mathrm{C}_{\max }=500 \mu \mathrm{M}\right)$, stigmasta-4,22-dien-3,6-dione $\left(\mathrm{C}_{\max }=10 \mu \mathrm{M}\right)$ and 3-O- $\beta$-Dglucopyranoside of sitosterol $\left(\mathrm{C}_{\max }=100 \mu \mathrm{M}\right)$.

The poor solubility of some of these compounds, such as stigmasta-4,22-dien-3,6-dione $\left(\mathrm{C}_{\max }=10 \mu \mathrm{M}\right)$ was undoubtedly a great disadvantage to test their putative cytotoxicity. However, maslinic acid induced $50 \%$ of cell death after $48 \mathrm{~h}$ of treatment $\left(\mathrm{IC}_{50}\right)$ at $0.075 \mathrm{mM}$, thus showing a powerful and specific cytotoxic effect. Among the six compounds which were prepared at $100 \mathrm{mM}$, it has been possible to determine an $\mathrm{IC}_{50}$ value for each of them, from the most to the less efficient (Table 1): Aminocinnamyl chlorohydrate $\left(\mathrm{IC}_{50}=0.1 \mathrm{mM}\right)$, stigmasta-4,22-dien-3-one $\left(\mathrm{IC}_{50}=0.3 \mathrm{mM}\right)$, 3-O-acetyl-5,6-epoxystigmast-22-ene-3-ol $\left(\mathrm{IC}_{50}=0.54 \mathrm{mM}\right)$, oleanolic acid $\left(\mathrm{IC}_{50}=0.7 \mathrm{mM}\right)$, amino-cinnamyl-2,3,4,6- $O$-tetraacetyl- $\alpha$-D-glucopyranoside $\left(\mathrm{IC}_{50}=0.88 \mathrm{mM}\right)$ and lupeol $\left(\mathrm{IC}_{50}=1 \mathrm{mM}\right)$. Thus, three of the tested compounds appear to have both good solubility and high specificity $\left(\mathrm{IC}_{50} \leq 0.3 \mathrm{mM}\right)$ to induce an efficient cellular toxicity in fibrosarcoma cells: Maslinic acid, aminocinnamyl chlorohydrate and stigmasta-4,22-dien-3-one. It is probable for the other compounds that the lack of one or both of these properties would be a disadvantage to trigger an effective in vivo cytotoxicity.

\section{Inter-Activity Models and Discussion}

The analyzed molecules of Table 1 are grouped on Gaussian (G) and Non-Gaussian (NG) sets, according with their activity ordering, see Figure 1; they will correspond with the trial/calibration and the test/predicting QSAR series, respectively.

\subsection{Calibration Quantitative Structure Inter-Activity Relationship (QSInAR)}

For Gaussian (trial) compounds one has the basic QSAR analysis: The correlation equations of the recorded activities with the Hansch parameters of Table 1, along the statistical indicators as the Pearson correlation (R) and the standard error of estimation (SEE), either as individual structure projected parameter-activity expressions:

$$
\begin{gathered}
A_{1}^{Q S A R}=3.1098-0.3634 \log P, \mathrm{R}_{1}=0.6732, \mathrm{SEE}_{1}=1.2264 \\
A_{2}^{Q S A R}=2.6528-0.0244 P O L, \mathrm{R}_{2}=0.1648, \mathrm{SEE}_{2}=1.6360 \\
A_{3}^{Q S A R}=0.5600-0.000009 \text { Etot }, \mathrm{R}_{3}=0.1647, \mathrm{SEE}_{3}=1.6360
\end{gathered}
$$

as well as the global structure-activity multi-regression equation:

$$
A^{Q S A R}=1.4045-1.6039 \log P+0.6226 P O L+0.00019 E t o t, \mathrm{R}_{\mathrm{QSAR}}=0.8358, \mathrm{SEE}_{\mathrm{QSAR}}=1.0326
$$


Figure 1. Representation of the cytotoxic activities $A=\log _{10}\left(1 / \mathrm{IC}_{50}\right)$ for the molecules of Table 1 on Gaussian (G) and Non-Gaussian (NG) curves as corresponding to the trial and testing sets of compounds in Table 1 , respectively.

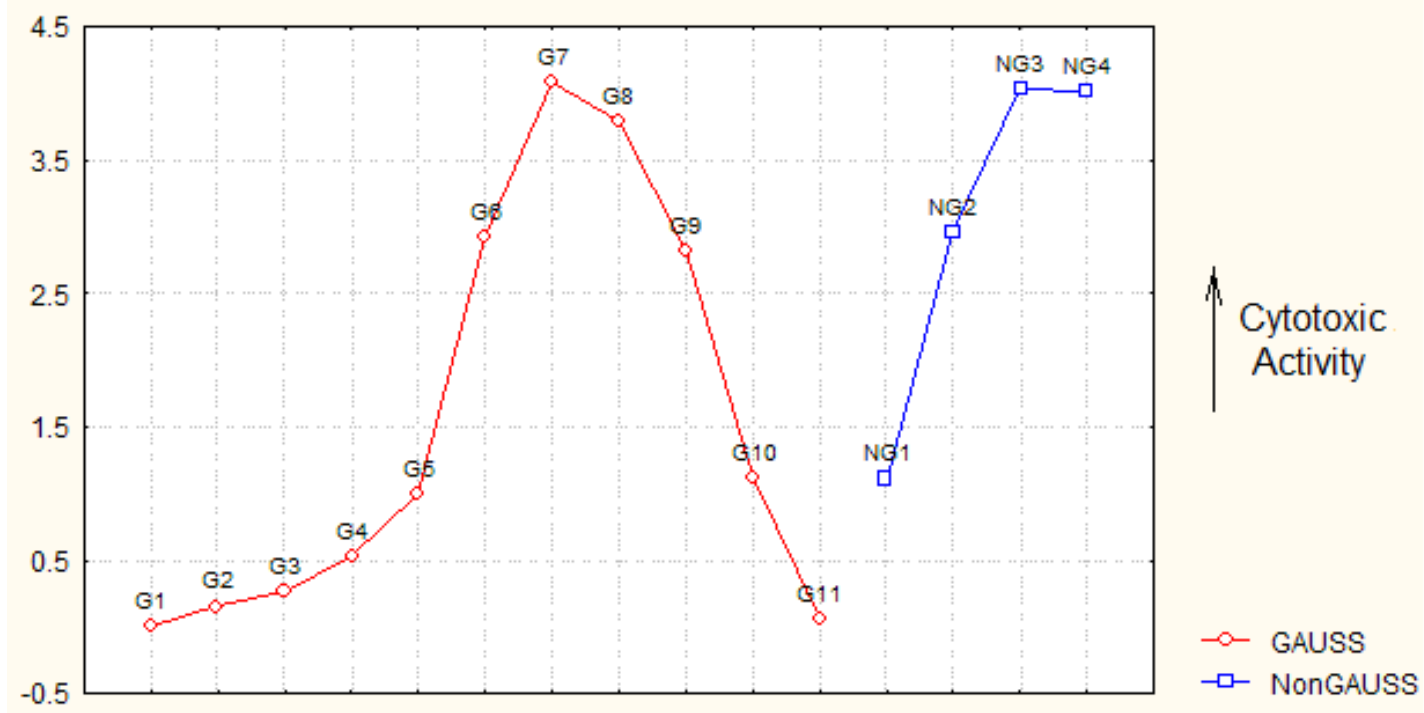

Equation (4) represents the ordinary QSAR predictive equation; note that the small correlation of the total energy in Equation (3) and with the very small coefficient in (4) is the indication that while the physicochemical properties of a small molecule (like steroids are) are definitely important (e.g., for transport), the adverse effect may stem from the interaction of such compound with a macromolecule (as the actual endpoints are very complex).

Such an observation further suggests that another sort of total-energy related quantity should be considered in multi-regressions; as such, not the energy itself but its projected activity given by Equation (3) is to be next considered; while doing the same with the other parameters too, one arrives to provide the so called inter-activity correlation or the quantitative structure-inter-activity relationship (QSInAR), that is correlating the activity of the Gaussian molecules of Table 1 with the projected activities on the Hansch structural parameters of Equations (1)-(3), and reported in Table 2.

Accordingly, the obtained multi-linear inter-activity regression of global activities of Table 1 with projected activities of Table 2 is unfolded for the training set with the form:

$$
\begin{gathered}
A^{Q \operatorname{SIn} A R}=67.3578+4.4138 A_{1}^{Q S A R}-25.5178 A_{2}^{Q S A R}-21.4027 A_{3}^{Q S A R} \\
\mathrm{R}_{\mathrm{QSInAR}}=0.8358, \mathrm{SEE}_{\mathrm{QSInAR}}=1.0326
\end{gathered}
$$

It is immediate that Equation (5) displays two major features, namely:

- It does not reproduce Equation (4) in regards to the computed coefficients of the structurallyprojected activities, while

- Displaying equal correlation respecting the direct structural-parameters-activity correlation of Equation (4).

The quantitative structure inter-activity relationship (QSInAR) may thus be used for further modeling and prediction on equal footing with the original QSAR modeling. The external prediction test is unfolded next. 
Table 2. The activities for the Gaussian (trial) molecules of Table 1 as computed by Equations (1)-(3).

\begin{tabular}{|c|c|c|c|}
\hline Index & $\mathrm{A}_{1}{ }^{\mathrm{QSAR}}$ & $\mathrm{A}_{2}{ }^{\mathrm{QSAR}}$ & $\mathbf{A}_{3}{ }^{Q S A R}$ \\
\hline G1 & 0.191 & 1.372 & 1.473 \\
\hline G2 & 0.449 & 1.355 & 1.583 \\
\hline G3 & 0.820 & 1.310 & 1.613 \\
\hline G4 & 0.133 & 1.416 & 1.438 \\
\hline G5 & 2.085 & 2.188 & 0.90 \\
\hline G6 & 2.358 & 1.638 & 1.493 \\
\hline G7 & 2.423 & 1.638 & 1.493 \\
\hline G8 & 2.866 & 1.310 & 1.954 \\
\hline G9 & 2.005 & 1.653 & 1.435 \\
\hline G10 & 0.729 & 1.339 & 1.641 \\
\hline G11 & 2.699 & 1.540 & 1.741 \\
\hline
\end{tabular}

\subsection{Predictive QSInAR}

However, in order to validate the present inter-activity approach, both QSAR and QSInAR-tests are now performed for the Non-Gaussian/NG (test) molecules of Table 1 by employing the Gaussian correlation Equations (4) and (5) to produce the data reported in Table 3, respectively. Finally, the correlations between the observed activities and those structurally either as ordinary QSAR or by actual QSInAR prediction analysis are presented in Equations (6) and (7) by employing the data of Tables 1 and 3 for the Non-Gaussian/NG molecules, respectively as:

$$
\begin{gathered}
A^{O B S}=-5.76267+3.04278 A^{Q S A R}, \mathrm{R}_{\mathrm{QSAR}}=0.9982, \mathrm{SEE}_{\mathrm{QSAR}}=0.10153 \\
A^{O B S}=-5.39564+3.35479 A^{Q S I n A R}, \mathrm{R}_{\mathrm{QSInAR}}=0.9991, \mathrm{SEE}_{\mathrm{QSInAR}}=0.07114
\end{gathered}
$$

The QSInAR comparative statistics between trial and test series of Table 1 and of Figure 1 are graphically represented in Figure 2 based on the basic Equations (5) and (7), respectively; the improvement of correlation for the test vs. trial correlation is evident, while being QSInAR superior with respect to ordinary QSAR analysis.

Table 3. The activities for the Non-Gaussian/NG (or test) molecules of Table 1 as computed upon Equations (1)-(3), alongside the predicted and computed activities as prescribed by Equations (4) and (5), respectively.

\begin{tabular}{cccccc}
\hline Index & $\mathbf{A}_{\mathbf{1}}{ }^{\text {QSAR }}$ & $\mathbf{A}_{\mathbf{2}}{ }^{\text {QSAR }}$ & $\mathbf{A}_{\mathbf{3}}{ }^{\text {QSAR }}$ & $\mathbf{A}^{\text {QSAR }}$ & $\mathbf{A}^{\text {QSInAR }}$ \\
\hline NG1 & 0.824 & 1.324 & 1.648 & 2.251 & 1.938 \\
NG2 & 2.292 & 1.343 & 1.902 & 2.898 & 2.500 \\
NG3 & 2.358 & 1.343 & 1.902 & 3.187 & 2.787 \\
NG4 & 2.256 & 1.298 & 1.933 & 3.224 & 2.822 \\
\hline
\end{tabular}


Figure 2. Scatter-plots representations of the observed $v s$. predicted correlations for the ordinary QSAR and inter-activity correlation QSInAR for both trial (Gaussian/G), the central figure, and for the test (Non-Gaussian/NG) sets, the two diagonal extreme insets, according with the regression Equations (4), (5) and (6), (7), respectively. Note that for the trial molecules the QSAR and QSInAR correlations are identically, see Equations (4) and (5), while for the test molecules the data of Table 3 were used.

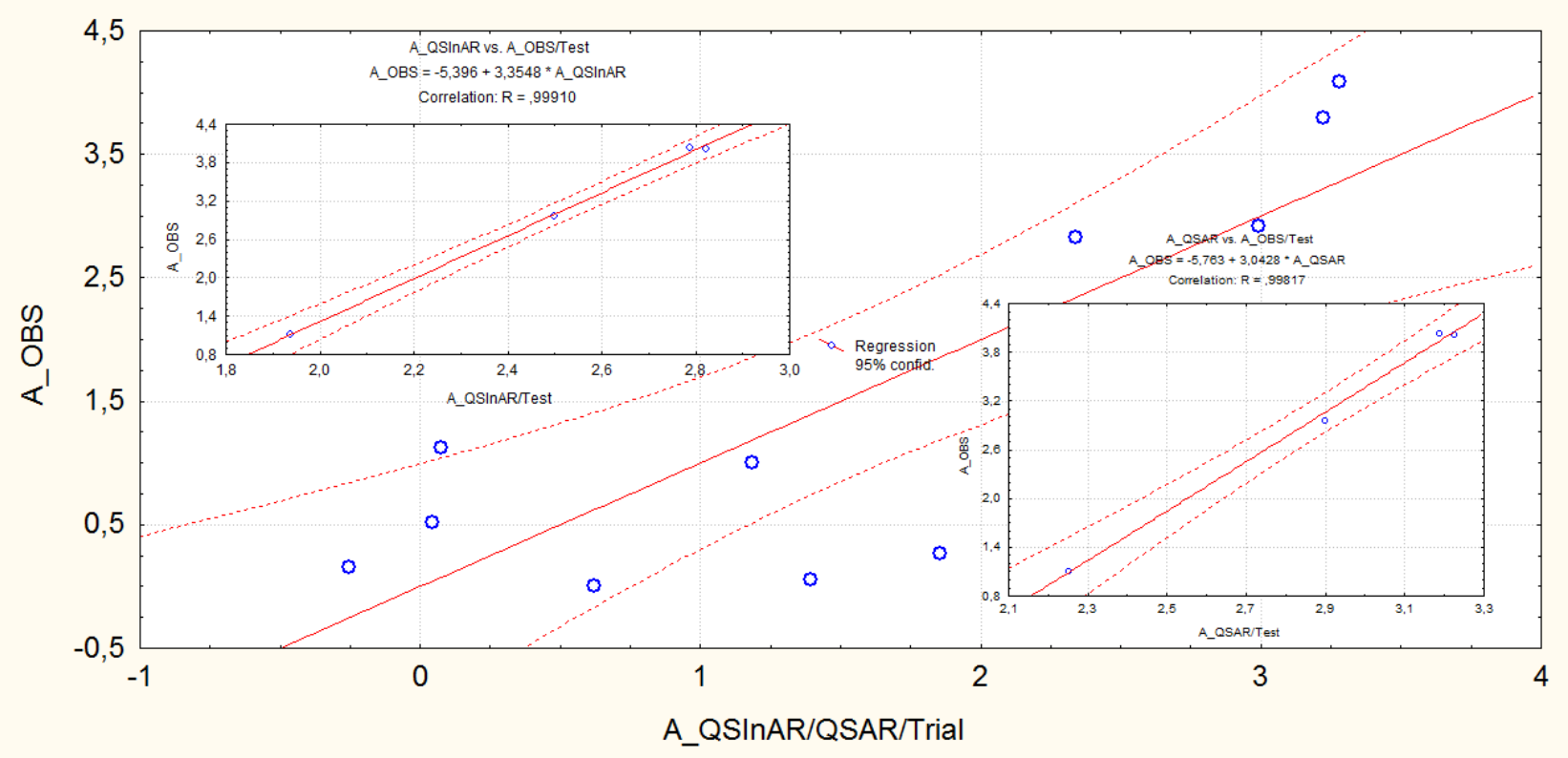

Overall, one can draw the main features revealed by the present analysis:

- The tested correlation performances are notably superior to those recorded for the calibration set for both QSAR and QSInAR frameworks; this way giving more confidence to the present models as reliable predictive activity tools for future designed steroids and triterpenes;

- Although the interactivity QSInAR model is equal with the direct QSAR one in the trialcorrelation set, see Equations (4) and (5), it is slightly superior for the externally tested one, see Equations (6) and (7);

- The consecrated triplet of Hansch parameters (LogP, POL and Etot) is sufficiently powerful to provide significant and reliable correlations of the structure with the measured activities of steroids and triterpenes, yet their projected activities are even more efficient in prediction when considered together in the inter-activity correlations;

- For hemisynthetic compounds 4 one record in Table 2 shows that it reaches the minimum $(\log \mathrm{P})$ projected computed (QSAR) activities in the Gaussian series; the extreme values are also seen for the hemisynthetic compound $\mathbf{5}$ for POL and Etot projected (QSAR) computed maximum and minimum activities, respectively; this means that these compounds are not predicted as active through the membrane transgression (compounds 4) and by the steric interaction (compound 5) but only by signal transduction (compound 5);

- Instead, the hemisynthetic compound 11, that was globally observed with the lowest cytotoxicity activity in Table 1 , it is predicted as having moderate anti-cancer activity especially by membrane diffusion, but also through polarizability and steric effects on tumoral 
cells; this means that this compound is especially adapted for membrane transduction, while being afterwards somehow inhibited by other (by this approach not revealed) molecular mechanisms during its interaction with tumor cell; further studies may improve upon replacing the total energy indicator, that is strongly depending on the size of the molecule and the number of hydrogen-bonding partner it features, with a key energy information relaying on the bindingsite models (atomistic, quasi-atomistic, virtual) which might serve to estimate the strength of the interaction;

- Polarizability has little influence on the recorded activity, see eq. (2), this way eliminating, in principle, the electrophilic mechanism specific to modeling genotoxic carcinogenity [24]; this is naturally since, in fact, the present study reveals the cytotoxic series that due to their induced cancer cell apoptosis acts contrarily to those producing cancer.

\section{Experimental}

\subsection{General}

A Bruker DRX-400 MHz spectrometer was used for 1D ${ }^{1} \mathrm{H}-\mathrm{NMR}$ studies. Melting points were measured in a Stuart Scientific Melting Point apparatus $\mathrm{SMP}_{3}$ and they are uncorrected. The matrix MALDI-TOFMS were a saturated 2,5-dihydroxybenzoic acid (2,5-DHB) solution in 50\% methyl alcohol, 0.1\% trifluoroacetic acid (TFA) and 2,5-dihydroxybenzoic acid (2,5-DHB, $1 \mathrm{M})$ solution in $50 \%$ acetonitrile / 50\% ultrapure water / $0.1 \%$ trifluoroacetic acid (TFA), respectively. All the depositions were made using the dried-droplet method. MALDI-TOFMS measurements were possible using a Bruker Reflex IV time-of-flight mass spectrometer (TOFMS) (Bruker-Daltonics, Bremen, Germany) equipped with the SCOUT 384 probe ion source, using a nitrogen pulsed laser $(337 \mathrm{~nm}$, model VSD-337ND, Laser Science Inc., Boston, MA, USA) with energy output of $400 \mu \mathrm{J} /$ pulse. Vacuum column chromatography, column chromatography and thin layer chromatography were performed respectively on silica gel $60 \mathrm{H}$ (particle size $90 \%<45 \mu \mathrm{m}$ ), 200-300 mesh silica gel, and silica gel GF254.

\subsection{Plant Material}

T. cordifolia A. Rich was collected from the central Yaoundé province of Cameroon and a specimen ( $\mathrm{N}^{\circ} 12830$ SRF Cam) has been deposited in the National Herbarium of Yaoundé, Cameroon.

\subsection{Isolation}

Dried stems of wild species of Triumfetta cordifolia A. Rich $(2.55 \mathrm{Kg})$ were cut into small pieces and powdered. Powder ( $250 \mathrm{~g}$ ) was extracted with methanol by heating for $8 \mathrm{~h}$. Methanol extract (60 g) was concentrated under vacuum and partitioned between water and ethyl acetate. Both phases were concentrated under vacuum to give $35 \mathrm{~g}$ of organic phase and $24 \mathrm{~g}$ of aqueous extract. The ethyl acetate extract was subjected to flash chromatography (silica gel, cyclohexane, cyclohexane-EtOAc 3:1-1:1-1:3, EtOAc, in order of increasing polarity) yielding five fractions. The cyclohexane-EtOAc (3:1) fraction was purified by column chromatography with different mixtures of cyclohexane-EtOAc yielding 217 fractions. The fractions 22-32 eluted with the mixture cyclohexane-EtOAc (9:1) yielded $32.0 \mathrm{mg}$ of lupeol (1). The ones (40-52) eluted with the mixture cyclohexane-EtOAc (17:3) yielded 45 
mg of oleanolic acid (2). The flash chromatography fraction from mixture of cyclohexane-EtOAc (1:1) yielded $125.0 \mathrm{mg}$ of stigmasterol (17) in the mixture cyclohexane-EtOAc (17:3), $2 \alpha$-Hydroxyoleanolic acid $(32.5 \mathrm{mg})$ was obtained from mixture of cyclohexane-EtOAc $(3: 1)$. The fraction obtained from mixture of cyclohexane-EtOAc (1:3) was eluted with $\mathrm{CH}_{2} \mathrm{Cl}_{2}-\mathrm{MeOH}$ mixtures of increasing polarity. The fractions 54-59 eluted with the 19:1 $\mathrm{CH}_{2} \mathrm{Cl}_{2}-\mathrm{MeOH}$ mixture gave the $\beta$-D-glucopyranoside of $\beta$-sitosterol (11.0 mg). The dried aqueous partition was extracted with acetone yielding $20 \mathrm{mg}$ of extract. This was eluted with a $\mathrm{CH}_{2} \mathrm{Cl}_{2}-\mathrm{MeOH}$ mixture of increasing polarity to yield 114 fractions. Fractions 74-80 eluted with 37:3 mixture of $\mathrm{CH}_{2} \mathrm{Cl}_{2}-\mathrm{MeOH}$ yielded tormentic acid (30 mg).

\subsection{Cellular Viability}

Given that solvents are often toxic to mammalian cells, the compounds were dissolved at high concentration $(100 \mathrm{mM})$. When the solubility did not allow us to reach $100 \mathrm{mM}$, we tried to prepare the most concentrated solutions possible. Lupeol, oleanolic acid, 3- $O$-acetyl-5,6-epoxystigmast-22ene-3-ol, stigmasta-4,22-dien-3-one and aminocinnamyl-2,3,4,6- $O$-tetraacetyl- $\beta$-D-glucopyranoside were prepared at $100 \mathrm{mM}$ in THF. Aminocinnamyl chlorohydrate was prepared at $100 \mathrm{mM}$ in DMSO. Stigmasterol and stigmasta-4,22-dien-3,6-dione were prepared at $50 \mathrm{mM}$ and $1 \mathrm{mM}$, respectively, in THF. Finally, maslinic acid and both tormentic acid and the 3-O- $\beta$-D-glucopyranoside of sistosterol were prepared in DMSO at $50 \mathrm{mM}$ and $10 \mathrm{mM}$, respectively.

The human HT1080 fibrosarcoma adherent cell line was cultured at $37{ }^{\circ} \mathrm{C}$ in a humidified atmosphere containing 5\% $\mathrm{CO}_{2}$ in Dulbecco's modified Eagle's medium (DMEM/F12) supplemented with $10 \%$ fetal bovine serum together with penicillin $(100 \mu \mathrm{g} / \mathrm{mL})$, streptomycin $(100 \mathrm{U} / \mathrm{mL})$ and glutamax $(1 \% \mathrm{v} / \mathrm{v})$ from Invitrogen. The cells were seeded in 12 well plates $\left(5 \times 10^{4}\right.$ cells/well). After $24 \mathrm{~h}$, the medium was replaced in each well by $1 \mathrm{~mL}$ of complete medium with the appropriate concentrations of the tested drugs. Corresponding controls with analogous concentrations of solvent were carried out in parallel. Cells were then incubated for $48 \mathrm{~h}$ and cellular viability was determined by flow cytometric analysis. Since type I (apoptosis), type II (autophagy) and type III (necrosis) cell death trigger permeabilization of mitochondria [25], overall cell death was then determined with the cationic lipophilic $\mathrm{DiOC}_{6}(3)$ dye (Invitrogen) which specifically probes mitochondrial membrane potential $(\Delta \Psi \mathrm{m})[26]$. A decrease in forward light scattering (FSC) was also checked to confirm the cell death process [27]. After drug treatment, the media from each well were kept in centrifuge tubes. The adherent cells were detached using trypsine, pooled with the corresponding media, centrifuged and resuspended in complete medium. Cells were then loaded with $100 \mathrm{nM} \mathrm{DiOC}_{6}$ (3) and incubated for $30 \mathrm{~min}$ at $37{ }^{\circ} \mathrm{C}$. Finally, cells were kept on ice prior flow cytometric analysis. Flow cytometric measurements were performed using a XL3C flow cytometer (Beckman-Coulter). Fluorescence was induced by the blue line of an argon ion laser $(488 \mathrm{~nm})$ at $15 \mathrm{~mW}$. Green fluorescence of DiOC $_{6}$ (3) was collected with a 525-nm band pass filter. Analyses were performed on $10^{4}$ cells. 


\subsection{Compounds Chosen from the Literature}

The compound 12 was obtained from the Research Institute of Luye Pharmacy, Yantai, China and its cytotoxic activity on human fibrosarcoma was tested [28]. Its melting point was measured on the Fisher micromelting point apparatus (hot-stage) and recorded uncorrected [29]. The compounds 6-9, and 13-15 were isolated and identified from Streptocaulon juventas [30] and their cytotoxic properties investigated $[31,32]$.

\section{Conclusions}

Since nowadays there is increasing interest in public health through various environmental interactions, the design of chemical compounds with little toxic effects on organisms or with anti-cancer effects remains at the forefront of actual molecular research either by experimental synthesis and computational modeling. In this context, the present work sought to combine both aspects (experimental and computational) in reporting new molecules in a series with pre-defined cytotoxicity activities. As such, the chemical synthesis of two new stigmast-en-ol/one (compounds $\mathbf{3}$ and $\mathbf{4}$ of Table 1) and aminocinnamyl- (compounds $\mathbf{5}$ and $\mathbf{1 1}$ of Table 1) derivatives were described and their cytotoxicity influence on human fibrosarcoma cells HT1080 analyzed by means of structural projected activities within the so called quantitative structure inter-activity relationship (QSIAR) modeling. The results are quite relevant, and are summarized below:

- The cytotoxicity of congeneric (both trial and test) series was considered and modeled as being projected on three fundamental Hansch parameters such as LogP, POL and Etot; it was found that the hydrophobicity $(\log \mathrm{P})$ is the main mechanism of interaction, while the polarizability (POL) has little influence on anti-tumoral mechanism-Rejecting this way the eventual generalization of Miller's electrophilic theory of carcinogenicity to its reversible evolution though cancer cells' apoptosis; in fact, while $\log \mathrm{P}$ was found to have little influence on carcinogenity [17], it appears here as having the main influence; one may conclude therefore that indeed the carcinogenity (formation of cancer cells) and the cytotoxicity (death of cancer cells) are complementary and not symmetrical with respect to QSAR analysis;

- The presented inter-activity QSInAR correlation equations show overall slightly better statistical prediction with respect to the custom QSAR counterpart, while providing equal performance for our trial set of newly hemisynthesyzed and isolated natural steroids and precursors triterpenes; this behavior assures the present reliable QSInAR analysis and the conclusions that result from it, namely:

o The newly hemisynthesized compounds are not all well suited to accounting for cytotoxicity of HT1080 cells, while their anti-cancer action is more relevant through the projection on some particular stages of molecular mechanism of ligand-receptor interaction, as following:

○ The compound stigmasta-4,22-dien-3-one (compound 4 in Table 1) is particularly not adapted for membrane transduction and therefore should be omitted from further clinical studies; 
- The compound aminocinnamyl chlorohydrate (compound 5 in Table 1) is less effective in tumoral apoptosis by steric signals but potentially active by polarization and therefore it should be further developed into another derivatives with improved structural projected activities;

- Aminocinnamyl-2,3,4,6-O-tetraacetyl- $\alpha$-D-glucopyranoside (compound $\mathbf{1 1}$ in Table 1) although it recorded the lowest observed overall molecular activity it is predicted to have moderately high cyt-activities as projected on all hydrophobic, polarizability and steric influences; such a behavior suggest that it undergoes successive molecular interaction within the cancer cells where some unrevealed inhibition interaction impedes its structurally-projected activities from being globally manifest towards tumor apoptosis.

While the ideal case will be the equal cytotoxicity performances at both local (structurallyprojected) and global (observed) activities, one may nevertheless rely on the inter-activity analysis and make further recommendations for new synthesis and molecular interactions and mechanism as far as it provides statistical relevant results for both trial and test congeneric molecules when physicochemical working structural indicators are included. The present work provides the first step in this combined experimental-QSInAR analysis and there is hope that it will be followed by other similar dedicated studies.

\section{Acknowledgements}

This work was supported by Romanian CNCS-UEFISCDI (former CNCSIS-UEFISCSU) project TE16/2010-2011 within the PN II-RU-TE-2009-1 framework, and partly by the grant POSDRU /21/1.5/G/38347. Louis P. Sandjo thanks Vincent Rincheval from Laboratory of Genetics and Cellular Biology of University of Versailles for support on the cytotoxicity assays and AUF-Eugen Ionescu for the mobility grant to West University of Timisoara. The anonymous referees are kindly thanked for their constructive comments on the paper.

\section{References and Notes}

1. Ma, C.-M.; Cai, S.-Q.; Cui, J.-R.; Wang, R.-Q.; Tu, P.-F.; Hattori, M.; Daneshtalab, M. The cytotoxic activity of ursolic acid derivatives. Eur. J. Med. Chem. 2005, 40, 582-589.

2. Awad, A.B.; Fink, C.S. Phytosterols as anticancer dietary components: Evidence and mechanism of action. J. Nutr. 2000, 130, 2127-2130.

3. Villaseñor, I.M.; Angelada, J.; Canlas, A.P.; Echegoyen, D. Bioactivity studies on $\beta$-Sitosterol and its glucoside. Phytother. Res. 2002, 16, 417-421.

4. Jamaluddin, F.; Mohamed, S.; Lajis, Md.N. Hypoglycaemic effect of Parkia speciosa seeds due to the synergistic action of $\beta$-sitosterol and stigmasterol. Food Chem. 1994, 49, 339-345.

5. Saez, J.; Cardona, W.; Espinal, D.; Blair, S.; Mesa, J.; Bocar, M.; Jossang, A. Five new steroids from Solanum nudum. Tetrahedron 1998, 54, 10771-10778. 
6. Itoh, H.; Ito, H.; Hibasami, H. Blazein of a new steroid isolated from Agaricus blazei Murrill (himematsutake) induces cell death and morphological change indicative of apoptotic chromatin condensation in human lung cancer LU99 and stomach cancer KATO III cells. Oncol. Rep. 2008, 20, 1359-1361.

7. Wang, Y.-S.; Yang, J.-H.; Luo, S.-D.; Zhang, H.-B.; Li, L. New cytotoxic steroid from Stachyurus himalaicus var. himalaicus. Molecules 2006, 11, 536-542.

8. Samadi, A.K.; Tong, X.; Mukerji, R.; Zhang, H.; Timmermann, B.N.; Cohen, M.S. Withaferin A, a cytotoxic steroid from Vassobia breviflora, induces apoptosis in human head and neck squamous cell carcinoma. J. Nat. Prod. 2010, 73, 1476-1481.

9. Shang, X.-Y.; Li, J.-J.; Liu, M.-T.; Li, S.; Liu, Y.; Wang, Y.-F.; Huang, X.; Jin, Z.-L. Cytotoxic steroids from Monascus purpureus-fermented rice. Steroids 2011, 76, 1185-1189.

10. Amagata, T.; Doi, M.; Tohgo, M.; Minoura, K.; Numata, A. Dankasterone, a new class of cytotoxic steroid produced by a Gymnascella species from a marine sponge. Chem. Commun. 1999, 1321-1322.

11. Zhang, H.-J.; Sun, J.-B.; Lin, H.-W.; Wang, Z.-L.; Tang, H.; Cheng, P.; Chen, W.-S.; Yi, Y.-H. A new cytotoxic cholesterol sulfate from marine sponge Halichondria rugosa. Nat. Prod. Res. 2007, 21, 953-958.

12. Brassart, B.; Gomez, D.; De Cian, A.; Paterski, R.; Montagnac, A.; Qui, K.-H.; Temime-Smaali, N.; Trentesaux, C.; Mergny, J.-L.; Gueritte, F.; et al. A new steroid derivative stabilizes G-quadruplexes and induces telomere uncapping in human tumor cells. Mol. Pharmacol. 2007, 72, 631-640.

13. Rickardson, L.; Fryknäs, M.; Dhar, S.; Lövborg, H.; Gullbo, J.; Rydåker, M.; Nygren, P.; Gustafsson, M.G.; Larsson, R.; Isaksson, A. Identification of molecular mechanisms for cellular drug resistance by combining drug activity and gene expression profiles. Br. J. Cancer 2005, 93, 483-492.

14. Caraglia, M.; Santini, D.; Marra, M.; Vincenzi, B.; Tonini, G.; Budillon, A. Emerging anti-cancer molecular mechanisms of aminobisphosphonates. Endocr. Relat. Cancer 2006, 13, 7-26.

15. Comprehensive Chemometrics: Chemical and Biochemical Data Analysis; Brown, S.D., Tauler, R., Walczak, B., Eds.; Elsevier: Amsterdam, The Nederland, 2009.

16. QSAR \& SPECTRAL-SAR in Computational Ecotoxicology; Putz, M.V., Ed; Apple Academics: Ontario, Canada, 2011.

17. Putz, M.V. Residual-QSAR. Implications for genotoxic carcinogenesis. Chem. Central J. 2011, 5, 29.

18. Hansch, C.; Kurup, A.; Garg, R.; Gao, H. Chem-bioinformatics and QSAR: A review of QSAR lacking positive hydrophobic terms. Chem. Rev. 2001, 101, 619-672.

19. Syamala, M.S.; Das, J.; Baskaran, S.; Chandrasekaran, S. A novel and highly $\beta$-selective epoxidation of $\Delta^{5}$-unsaturated steroids with permanganate ion. J. Org. Chem. 1992, 57, 1928-1930.

20. Li, S.-H.; Li, T.-S. Steroidal 5-en-3-ones, intermediates of the transformation of steroidal 5-en-3 $\beta$ ols to steroidal 4-en-3,6-diones oxidized by pyridinium dichromate and pyridinium chlorochromate. Steroids 1998, 63, 76-79.

21. Lin, W.; Zhang, X.; He, Z.; Jin, Y.; Gong, L.; Mi, A. Reduction of azides to amines or amides with zinc and ammonium chloride as reducing agent. Syn. Comm. 2002, 32, 3279-3284. 
22. Chowdhury, B.T.; Bhat, G.K. Current concepts in apoptosis: The physiological suicide program revisited. Cell. Mol. Biol. Lett. 2006, 11, 506-525.

23. Program Package, HyperChem 7.01; Hypercube, Inc.: Gainesville, FL, USA, 2002.

24. Miller, E.C.; Miller, J.A. Searches for ultimate chemical carcinogens and their reactions with cellular macromolecules. Cancer 1981, 47, 2327-2345.

25. Bras, M.; Queenan, B.; Susin, S.A. Programmed cell death via mitochondria: Different modes of dying. Biochemistry (Moscow) 2005, 2, 231-239.

26. Galluzi, L.; Zamzami, N.; de La Motte-Rouge, T.; Lemaire, C.; Brenner C.; Kroemer, G. Methods for the assessment of mitochondrial membrane permeabilization in apoptosis. Apoptosis 2007, 12, 803-813.

27. Darzynkiewicz, Z.; Juan, G.; Li, X.; Gorczyca, W.; Murakami, T.; Traganos, F. Cytometry in cell necrobiology: analysis of apoptosis and accidental cell death (necrosis). Cytometry 1997, 27, 1-20.

28. Li, G.; Wang, Z.; Sun, Y.; Liu, K.; Wang, Z. Ginsenoside 20(S)-protopanaxadiol inhibits the proliferation and invasion of human fibrosarcoma HT1080 cells. Basic Clin. Pharmacol. Toxicol. 2006, $98,588-592$.

29. Im, K.S.; Chang, E.H.; Je, N.G. A modified alkaline hydrolysis of total ginsenosides yielding genuine aglycones and prosapogenols. Arch. Pharm. Res. 1995, 18, 454-457.

30. Ueda, J.-Y.; Tezuka, Y.; Banskota, A.H.; Tran, Q.L.; Tran, Q.K.; Saiki, I.; Kadota, S. Constituents of the Vietnamese medicinal plant Streptocaulon juventas and their antiproliferative activity against the human HT-1080 fibrosarcoma cell line. J. Nat. Prod. 2003, 66, 1427-1433.

31. Karle, I.L.; Karle, J. The crystal structure of digitoxigenin, $\mathrm{C}_{23} \mathrm{H}_{34} \mathrm{O}_{4}$. Acta Cryst. 1969, 25, 434-442.

32. Khine, M.M. Isolation and characterization of phytoconstituents from myanmar medicinal plants. In Dissertation; Martin-Luther-Universität Halle-Wittenberg: Halle, Germany, 2006; pp. 114-119.

Sample Availability: Samples of the compounds are available from the author Louis P. Sandjo.

(C) 2011 by the authors; licensee MDPI, Basel, Switzerland. This article is an open access article distributed under the terms and conditions of the Creative Commons Attribution license (http://creativecommons.org/licenses/by/3.0/). 